E3S Web of Conferences 1, 17006 (2013)

DOI: $10.1051 / \mathrm{e} 3$ sconf/20130117006

(c) Owned by the authors, published by EDP Sciences, 2013

\title{
Mercury simulations within GMOS: Analysis of short-term observational episodes
}

\author{
O. Travnikov $^{1}$, I. M. Hedgecock ${ }^{2}$, V. Matthias ${ }^{3}$, A. Dastoor ${ }^{4}$ and C-J. Lin ${ }^{5}$ \\ ${ }^{1}$ Meteorological Synthesizing Centre - East of EMEP, Krasina pereulok, 16/1, 123056 Moscow, RUSSIA, \\ oleg.travnikov@msceast.org \\ ${ }^{2}$ CNR-Institute of Atmospheric Pollution Research, c/o: UNICAL (Polifunzionale), 87036 \\ Rende, ITALY, \\ i.hedgecock@iia.cnr.it \\ ${ }^{3}$ Helmholtz-Zentrum Geesthacht Zentrum für Material und Küstenforschung GmbH Max-Planck-Straße 1, 21502 \\ Geesthacht, GERMANY, \\ volker.matthias@hzg.de \\ ${ }^{4}$ Air Quality Research Division, Science and Technology Branch, Environment Canada, 2121 Trans Canada Highway, \\ Dorval, Quebec H9P 1J3, CANADA, \\ ashu.dastoor@ec.gc.ca \\ ${ }^{5}$ Department of Civil Engineering, Lamar University, Beaumont, TX 77710, USA, \\ jerry.lin@lamar.edu
}

\begin{abstract}
A number of contemporary chemical transport models for mercury are applied within the framework of the EU GMOS project to study principal processes of mercury transport and transformations in the atmosphere. Each model is involved in simulation of short-term episodes corresponding to particular $\mathrm{Hg}$ measurement campaigns in Europe and other regions. In order to evaluate different physical and chemical mechanisms the models perform sensitivity runs with various parameterizations and/or combinations of considered processes. The modeling results are compared to detailed measurements of $\mathrm{Hg}$ species $\left(\mathrm{Hg}^{0} / \mathrm{TGM}\right.$, $\mathrm{RGM}, \mathrm{HgP}$ ) with high temporal resolution (hours) aiming at reproduction of short-term temporal variability of $\mathrm{Hg}$ air concentration.
\end{abstract}

Key words: Mercury simulation, chemical transport models, short-term episodes, GMOS project

\section{Introduction}

Mercury $(\mathrm{Hg})$ is widely recognised as a toxic chemical capable of long-range transport, bioaccumulation in the environment and adverse impact on human health and the environment. Due to its long residence time in the free troposphere it can be easily transported between continents and affect vulnerable ecosystems of remote regions (Arctic, Antarctica, Open Ocean, etc.) Therefore evaluation of present-day $\mathrm{Hg}$ pollution levels as well as forecasts of future changes should take into account the global character of $\mathrm{Hg}$ atmospheric transport and dynamics of $\mathrm{Hg}$ emission changes in different continents. In this aspect, the application of global chemical transport models can supplement direct measurements of $\mathrm{Hg}$ concentration and deposition levels giving more comprehensive and detailed information on $\mathrm{Hg}$ pollution.

Applications of mercury atmospheric models on hemispheric and global scales performed by different scientific groups demonstrated satisfactory ability to evaluate background levels of $\mathrm{Hg}$ and its intercontinental transport as well as reasonable agreement with available measurements (Christensen et al., 2004; Seigneur et al., 2004; Travnikov, 2005; Selin et al., 2007; Dastoor et al., 2009; Jung et al., 2009; Holmes, 2010). However, current knowledge on $\mathrm{Hg}$ behaviour in the atmosphere and its potential to cycling between different environmental media is still incomplete. There are significant gaps in the understanding of chemical processes affecting $\mathrm{Hg}$ atmospheric transport and deposition, characteristics of the air-surface exchange and processes responsible for re-emission of $\mathrm{Hg}$ to the atmosphere.

Development and application of chemical transport models are an essential part of the EU GMOS project (Global Mercury Observation System) funded by the European Commission 7th Framework Programme (DG Research). The project is aimed at (i) establishment of a global monitoring system for mercury including 
land-based, over-water and aircraft observations; (ii) improvement and validation of regional and global scale atmospheric mercury models; (iii) model application to evaluate source-receptor relationships, temporal trends and scenarios; (iv) development of an interoperable system for dissemination of the project output data.

The program of model activities within GMOS includes a number of Tasks on improvement and further development of global and regional scale models and their application for the assessment of present and future concentration and deposition levels, hindcasting historical trends, and evaluation of source-receptor relationships. The first phase includes simulation of short-term observational episodes involving detailed measurements of $\mathrm{Hg}$ species at ground monitoring sites, ship-based and aircraft platforms. Global and regional scale models both of the GMOS model consortium (GLEMOS, ECHMERIT, WRF-Chem, CMAQ-Hg) and of external partners of the project are involved in the study.

\section{Multi-model simulations and analysis}

A number of contemporary chemical transport models for mercury are applied to study principal processes of $\mathrm{Hg}$ transport and transformations in the atmosphere. Each model is involved in simulation of short-term episodes corresponding to particular $\mathrm{Hg}$ measurement campaigns in Europe and other regions. The observational episodes are selected to characterize $\mathrm{Hg}$ behavior in different atmospheric environments:

- Continental boundary layer (EMEP measurements at site Langenbrügge, Germany, 2009)

- Marine boundary layer
(RV Urania cruise, Mediterranean Sea, June 2009)

- Free troposphere and UT/LS

(CARIBIC project, Europe/global, 2009; INTEX-B campaign, North America, 2006).

In order to evaluate different physical and chemical mechanisms the models perform simulations of the observational episodes with various parameterizations and/or combinations of considered processes. The modeling results are compared to measurements of $\mathrm{Hg}$ species $\left(\mathrm{Hg}^{0} / \mathrm{TGM}, \mathrm{RGM}, \mathrm{HgP}\right)$ with high temporal resolution (hours) aiming at reproduction of short-term temporal variability of $\mathrm{Hg}$ air concentration. The sensitivity analysis is focused on the following questions:

- What are relative contributions of redox chemistry and direct anthropogenic emissions to air concentration of oxidized $\mathrm{Hg}$ forms (RGM, $\mathrm{HgP}$ ) in the CBL and deposition to the ground?

- What is the speciation of $\mathrm{Hg}$ anthropogenic emissions?

- What are the major mechanisms of $\mathrm{Hg}$ oxidation in the CBL and MBL?

- What is the physical state of the oxidation products (gaseous or particulate)?

- What is the role of the air-surface exchange in $\mathrm{Hg}$ cycling in the MBL?

- What are the prevailing mechanisms of $\mathrm{Hg}$ oxidation and removal in the UT/LS?

An example of the model analysis of $\mathrm{Hg}^{0}$ concentrations in the CBL measured at the German monitoring site Langenbrügge (DE02) of the EMEP monitoring network is given in Fig. 1.

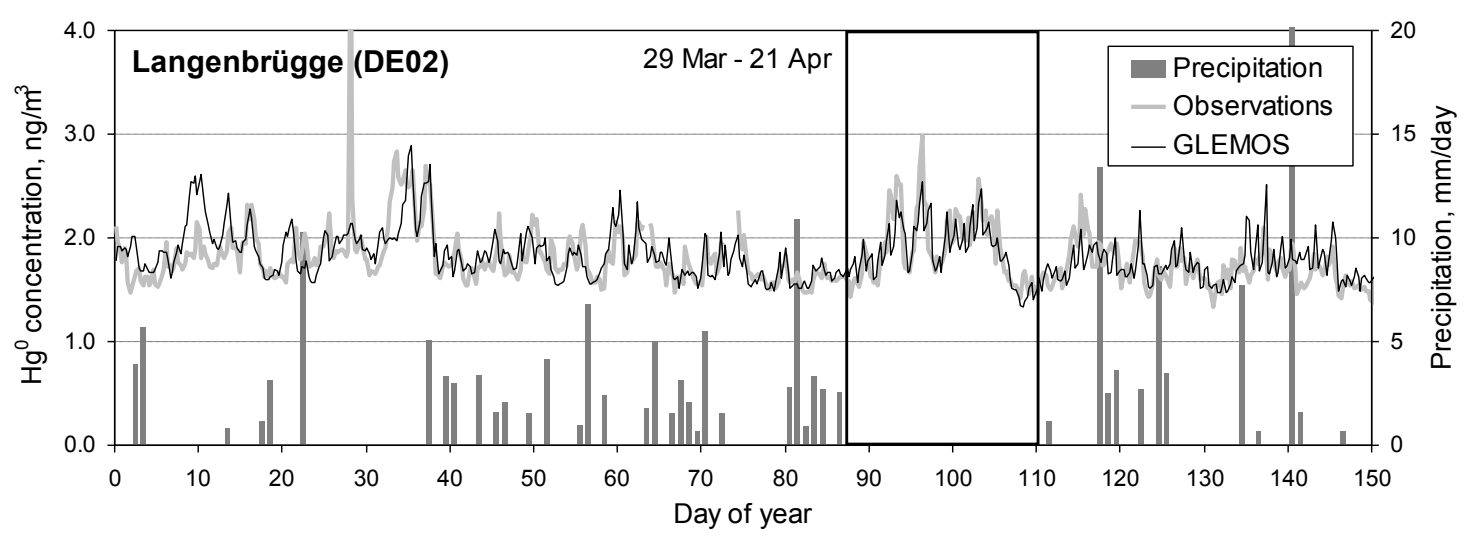

Fig. 1. Comparison of simulated and observed air concentrations of $\mathrm{Hg}^{0}$ at site Langenbrügge, Germany (DE02) in the first half of 2009. The rectangle shows a short-term episode with no precipitation chosen for the analysis of the gas-particle partitioning in the.

\section{References}

Christensen JH., et al. Modelling of mercury in the Arctic with the Danish Eulerian Hemispheric Model. Atmospheric Chemistry \& Physics 2004; 4:
2251-2257.

Dastoor AP and Davignon D. Global mercury modeling at Environment Canada. In Pirrone $\mathrm{N}$ and Mason RP (eds.) Mercury Fate and Transport in the Global Atmosphere: Emissions, Measurements, and Models. 
Springer, New York, 2009; pp. 519-531

Holmes CD, Jacob DJ, Corbitt ES, Mao J, Yang X, Talbot R, and Slemr F. Global atmospheric model for mercury including oxidation by bromine atoms. Atmos. Chem. Phys. 2010; 10: 12037-12057

Jung G, Hedgecock IM, Pirrone N. ECHMERIT V1.0 - a new global fully coupled mercury-chemistry and transport model. Geosci. Model Dev. 2009; 2: 175-195.

Seigneur C, et al. Global Source Attribution for Mercury
Deposition in the United States. Environmental Science \& Technology 2004: 38: 15.

Selin NE, et al. Chemical cycling and deposition of atmospheric mercury: Global constraints from observations. J. Geophys. Res. 2007; 112: D02308.

Travnikov O. Contribution of the intercontinental atmospheric transport to mercury pollution in the Northern Hemisphere. Atmos. Environ. 2005; 39: 7541-7548. 